\title{
AHP-TOPSIS for Selection Step of Land Title Deed Registration Process
}

\author{
Eko Sebastian ${ }^{1}$ \\ Department of Computer Education, Faculty of Teaching \\ and Education, Mulawarman University, Indonesia \\ ekosebastian1989@gmail.com
}

\author{
Vina Kamila ${ }^{2}$ \\ Department of Informatics Management \\ STMIK Widya Cipta Dharma, Samarinda \\ vinakamila@gmail.com
}

\begin{abstract}
This study discusses about a decision support system that help the registration process of land deed title ("Akta/Sertifikat Tanah" in Indonesian) that is required to obtain legal certainty for land, rights holders and other parties concerned with the land. AHP (Analytical Hierarchy Process) TOPSIS (Technique Order Preference by similarity to ideal solution) is a solution that can be used for decision making for land deed official (PPAT or "Pejabat Pembuat Akta Tanah" in Indonesian) to select which documents that should be processed based on the priority. The criteria's used in AHP method to determine the priority is data of submitted land tittle deed, land books, registration base maps, registration maps, land lists, letter of measurement, lists of names, and land status. TOPSIS data processing is done after AHP weighting process finished to make a list of document queue based on priority. The result of this research shows that fewer variables could represent all the variables and can assess and rank with the quality of good decisions and provide variables that focused on improvement.
\end{abstract}

Keywords-decision support systems; AHP TOPSIS; legal certainty for land rights holders; land deed title registration process

\section{INTRODUCTION}

Land plays an important role in human life, for example, land can be used as assets or investment for the future. As a developing country, Indonesia, with a sizeable population, demographic problems often affect the people, especially those related to land. Uncertainty land ownership is one of the biggest problem in Indonesia especially here in Kalimantan. The dispute of land ownership rights can be lead to some social problems.

Registration of land title deed is conducted to obtain legal certainty for holders of land rights as well as other parties concerned with the land. By registering and obtaining a certificate (land title deed), the holder of land rights has strong evidence of the land. The problems could occurred in the process. For example, problem with Standard Operating Procedures for Land Regulations and Services (SPOPP); the problem of land borders is the most occurred problem in the Land Affairs Office. For example, by shifting the existing landmarks or borders. This would certainly be a conflict between the landowner and the party who try to take the land right [18].

In addition to the land border issue, what usually happens is the existence of fake certificate or land title deed forgery. The fake certificates are often used in inheritance certificates, seal sales papers or as debt guarantees. This fake certificate could be one of the causes of land conflicts.

Badan Pertanahan Nasional (Indonesian government land agency) is the only agency who can make official land tittle deed. A land deed official (public officials who are authorized to make the deeds on the land) help the agency to check the originality of the deed and make sure the registration of the land title deed is processed without problem [18].

The use of Analytical Hierarchical Process (AHP) is illustrated in a study measuring the most important factors [8]. In today's increasingly competitive environment, an accurate and precise evaluation of financial performance is important for a company that targets to successfully maintain its market position and protect their market share against potential future risks.

Method of TOPSIS (Technique for Order Preference by Similarity to Ideal Solution) is used to determine whether the results of TOPSIS rank and rank results registrant value of land deed certificate overlapped or not [1]. Evaluating the performance of land tittle deed registration processes is an important issue. Not only for those who sign up for the right to right in the land tittle deed, but also for other land deed officials residing in the same sector. The proposed approach of this study use Fuzzy Analytic Hierarchy Process (FAHP) and TOPSIS. FAHP is used in generating the weight of criteria in decision making.

TOPSIS method is also used to evaluate the performance of fifteen Turkish cement companies on the Istanbul Stock Exchange [6]. This method simplify complicated metric distance method, and propose an algorithm to modify the AHPTOPSIS Chen, also presents a numerical example and build a practical matter of suppliers to verify the proposed method and compare it with other methods [21]. Credit quality has become the center of attention recently. The classical MCDM TOPSIS was introduced to evaluate credit quality at 8 Air Conditioning companies, where the results of the evaluation have proved that the feasibility and effectiveness of TOPSIS that can significantly influence the evaluation results [22].

This study use the method in assessment process, where the assessment process in the previous research is still subjective, whereas in this research is objective by using the assessment 
scale. So in the assessment process is not dependent on the personal but can be done by the system automatically.

This study discusses the selection of land tittle deed for land deed official. The criteria used are submitted land tittle deed, land books, registration base maps, registration maps, land lists, letter of measurement, lists of names, and land status. The applicant or customer who will perform the certification process will be assessed objectively. The result of the argument from the judgment, can be used as a benchmark in decision makers.

\section{Methodology}

\section{A. Land Deed Official (Notaris PPAT in Bahasa Indonesia)}

Notary (deed official) is a public official authorized to make authentic deeds and other powers as intended in law. Notary law is contained in Indonesian act no. 30 of 2004 chapter III on authority, obligations and restrictions. The first part of Article 15, the notary, is authorized to make an authentic deed of all acts, agreements and statutes which shall be by law of the law intended by interested parties to be declared in an authentic deed, guaranteeing the date of making the deed, preserving the deed, granting the copy, Excerpts of deeds, all of which during the making of such deeds are not also assigned or excluded to other officials or other persons established by law.

Government Regulation of the Republic of Indonesia Number 24 of 1997 on Land Registry chapter 1 General Regulations, Land Registration is a series of activities. The continuous, sustained and regular undertakings of the government include collection, sorting, bookkeeping, and presenting and maintaining physical data and juridical data, in the form of maps and lists, on the plots of land and apartment units, including the provision of letters The proof of their right to the existing land rights and the ownership rights of the apartment units and the certain rights that burden them.

\section{B. Decision Support System (DSS)}

Decision Support System (DSS) is a system capable of providing problem-solving and communications capabilities for problems with semi-structured and unstructured conditions. This system is used to assist decision making in semistructured situations and unstructured situations, where nobody knows exactly how decisions should be made [4]. DSS aims to provide information, guide, provide predictions and lead to users of information in order to make better decisions.

DSS is an implementation of decision-making theories that have been introduced by sciences such as operation research and science management. The only difference is that if you first look for problem solving you have to manually calculate iteration (usually to find the minimum, maximum, or Optimum), now PC has offered its ability to solve the same problem in a relatively short time. Sprague and Watson define Decision Support System (DSS) as a system that has five main characteristics [14]:

- Computer-based systems,

- Used to help decision makers,
- To solve complicated problems that are impossible to do with manual calculations,

- Through interactive simulation way,

- Data and model analysis as main components.

Generally Decision Support System is built by three major components of database Management, Model Base and Software System / User Interface.

\section{C. $A H P$}

AHP developed Dr. Thomas L. Saaty of the Wharton School of Business in 1970 for organizing information and judgment in having the most preferred alternative [20]. AHP is a method of breaking complex / complex problems in an unstructured situation into component parts. Organize this part or variable into a hierarchical order form, then assign a numerical value to the subjective assessment of the relative importance of each variable and synthesize the assessment for which variable has the highest priority that will affect the settlement of the situation. The AHP combines personal judgment and judgment in a logical and influenced way imagination, experience, and knowledge to construct a hierarchy of problems based on logic, intuition as well as experience to give consideration [20]. The procedure in $A H P$ method consists of several stages, namely:

\section{1) Prepare the hierarchy of problems encountered}

Preparation of hierarchy is by determining the objectives that are the target system as a whole at the top level. The next level consists of criteria for assessing or considering alternatives and determining those alternatives. Each criterion can have sub criteria below and each criterion can have an intensity value of each.

\section{2) Define the priority of the element}

The first step in determining the priority of the elements is to make pairwise comparisons, i.e., comparing the elements in pairs according to the given criteria by using the matrix form. A simple, robust matrix that offers a framework for checking consistency, obtaining additional information by making all possible comparisons and analyzing the overall priority sensitivity to change considerations. The pairwise comparison process starts from the topmost level of the hierarchy to select criteria, such as $\mathrm{C}$, then from the lower levels the elements will be compared, e.g. A1, A2, A3, A4, A5, then the arrangement of elements in a matrix, Table I.

TABLE I. QUANTITATIVE SCALES IN AHP METHOD

\begin{tabular}{|c|c|c|c|c|c|}
\hline C & A1 & A2 & A3 & A4 & A5 \\
\hline A1 & 1 & & & & \\
\hline A2 & & 1 & & & \\
\hline A3 & & & 1 & & \\
\hline A4 & & & & 1 & \\
\hline A5 & & & & & 1 \\
\hline
\end{tabular}

3) Some steps in this process :

Fill in a pairwise matrix by using a number to represent the relative importance of one element to the other element in the form of a scale from 1 to 9 . This scale defines and explains 
values 1 to 9 for consideration in pairwise pairs of elements at each hierarchical level of a Criteria at a higher level. If an element in the matrix and compared with itself, it is given a value of 1 . If $i$ than $j$ get a certain value, then $j$ than $i$ was opposite. Here is a quantitative scale of 1 to 9 to assess the importance of an element with other elements.

TABLE II. QUANTITATIVE SCALES IN AHP METHOD

\begin{tabular}{|c|l|l|}
\hline Intensity of Interest & \multicolumn{1}{|c|}{ Meaning / Meaning } & \multicolumn{1}{|c|}{ Explanation } \\
\hline 1 & $\begin{array}{l}\text { Both elements are } \\
\text { equally important }\end{array}$ & $\begin{array}{l}\text { Two elements have the same } \\
\text { effect on purpose }\end{array}$ \\
\hline 3 & $\begin{array}{l}\text { One element is slightly } \\
\text { more important than the } \\
\text { other elements }\end{array}$ & $\begin{array}{l}\text { Experience and judgment } \\
\text { support a little more than any } \\
\text { other element }\end{array}$ \\
\hline 5 & $\begin{array}{l}\text { One element is more } \\
\text { important than other } \\
\text { elements }\end{array}$ & $\begin{array}{l}\text { Experience and judgment are } \\
\text { very strong in favor of one } \\
\text { element over the other }\end{array}$ \\
\hline 7 & $\begin{array}{l}\text { One element is clearly } \\
\text { more important than the } \\
\text { other }\end{array}$ & $\begin{array}{l}\text { One strong element in advocacy } \\
\text { and dominance is seen in } \\
\text { practice }\end{array}$ \\
\hline $2,4,6,8$ & $\begin{array}{l}\text { One element is } \\
\text { absolutely essential from } \\
\text { other elements }\end{array}$ & $\begin{array}{l}\text { Evidence that supports one } \\
\text { element against other elements } \\
\text { has the highest degree of } \\
\text { affirmation that might be } \\
\text { corroborating }\end{array}$ \\
\hline The opposite & $\begin{array}{l}\text { Values between 2 } \\
\text { adjacent consideration } \\
\text { values }\end{array}$ & $\begin{array}{l}\text { This value is given when there } \\
\text { are two compromises between } \\
\text { the 2 options }\end{array}$ \\
\hline reverse value compared with i
\end{tabular}

\section{4) Synthesis}

Considerations for paired comparisons in synthesis to gain overall priority:

- Sums up the values of each column in the matrix.

- Divide each value of the column by the corresponding column total to obtain the normalization of the matrix.

- Sums the value of each matrix and divides it by the number of elements to get the average value.

- Measure consistency.

Consistency is important to get valid results in the real world. AHP measure consideration consistency with consistency ratio (ratio consistency). Consistency value ratio should be less than $5 \%$ for $3 \times 3$ matrices, $9 \%$ for $4 \times 4$ matrices and $10 \%$ for larger matrices. If more than the ratio of the limit then the matrix comparison value is done again. Steps to calculate the value of consistency ratio are:

- Multiplying the value in the first column with the relative priority of the first element, the value in the second column with the relative priority of the second element, and so on.

- Sums up each row.

- The result of the sum of the rows is shared with the relevant relative priority element.
- Dividing the above results with many existing elements, the result is called Eigen value $(\lambda \max )$, for matrices see Table II.

- Calculating the consistency index (consistency index) with the formula:

$$
C I=(\lambda \max -\mathrm{n}) / \mathrm{n} \text {. }
$$

$$
\begin{aligned}
& C I=\text { Consistency Index } \\
& \lambda \max =\text { Eigen Value } \\
& n=\text { Many elements }
\end{aligned}
$$

- Calculated the consistency ratio (CR) by the formula:

$$
\begin{gathered}
C R=\frac{C I}{R C} \\
C R=\text { Consistency Ratio } \\
C I=\text { Consistency Index } \\
R C=\text { Random Consistency }
\end{gathered}
$$

Random matrix with a scale of 1 to 9 and their ratings have upside as random consistency (RC). Based on calculations using 500 samples Saaty, if consideration randomly select from a scale of $1 / 9,1 / 8, \ldots, 1,2, \ldots, 9$ will be obtained average consistency for different matrix can be seen in Table III.

TABLE III. THE AVERAGE VALUE OF CONSISTENCY

\begin{tabular}{|c|c|}
\hline Matrix Size & Random Consistency \\
\hline 1 & 0.00 \\
\hline 2 & 0.00 \\
\hline 3 & 0.58 \\
\hline 4 & 0.90 \\
\hline 5 & 1.12 \\
\hline 6 & 1.24 \\
\hline 7 & 1.32 \\
\hline 8 & 1.41 \\
\hline 9 & 1.45 \\
\hline 10 & 1.49 \\
\hline
\end{tabular}

\section{TOPSIS (Technique For Others Reference by Similarity to Ideal Solution)}

TOPSIS is one of the multi-criteria decision-making methods first introduced by Yoon and Hwang (1981). TOPSIS uses the principle that the chosen alternative must have the shortest distance from the ideal solution and the longest distance from the ideal solution from a geometric point of view by using the distance between two points to determine the relative proximity of an alternative with the optimal solution.

The positive ideal solution is defined as the sum of all the best attainable values for each attribute, while the ideal negative solution consists of all the worst values achieved for each attribute. TOPSIS considers both, the distance to the ideal solution and the distance to the ideal solution by taking the proximity relative to the positive ideal solution. The algorithm basic steps of TOPSIS as follows.

a. Each alternative rank 
TOPSIS requires performance ranking of each alternative $A_{i}$ on each of the normalized $C_{j}$ criteria. This can be seen from the formula below:

$$
r i j=\frac{X i j}{\sqrt{\sum_{i=1}^{m} X_{i j}^{2}}}
$$

Where:

with $\mathrm{i}=1,2, \ldots \mathrm{m}$; and $\mathrm{j}=1,2, \ldots \ldots \mathrm{n}$;

$\mathrm{r}_{\mathrm{ij}}=$ value normalized performance rating

$\mathrm{x}_{\mathrm{ij}}=$ value of each alternative on each criterion

$A_{i}$ is the alternative of an activity. $C_{j}$ is a type of criteria.

b. Declined Matrix of Decisions Weighted

$$
Y_{i j}=W_{i} r_{i j}
$$

with $\mathrm{i}=1,2, \ldots, \mathrm{m}$ and $\mathrm{j}=1,2, \ldots, \mathrm{n}$

Where:

$\mathrm{W}_{\mathrm{j}}=$ value of the weight of each criterion

$\mathrm{r}_{\mathrm{ij}}=$ value normalized performance rating

c. Positive and Negative Positive Solutions

The ideal A + positive solution and the ideal A-negative solution can be determined based on the normalized weighted rank (Yij) as follows:

$$
\begin{aligned}
& A^{+}=\left(y_{1}^{+}, y_{2}^{+}, \ldots, y_{n}^{+}\right) \\
& A^{-}=\left(y_{1}^{-}, y_{2}^{-}, \ldots, y_{n}^{-}\right)
\end{aligned}
$$

Where:

$$
\begin{aligned}
& y_{j}^{+}: \text {Max } \mathrm{y}_{\mathrm{ij}} \text { if } \mathrm{j} \text { is an attribute profits } \\
& \text { Max } \mathrm{y}_{\mathrm{ij}} \text { if } \mathrm{j} \text { is an attribute charge } \\
& y_{j}^{-}: \text {Min } \mathrm{y}_{\mathrm{ij}} \text { if } \mathrm{j} \text { is an attribute profits } \\
& \text { Min } \mathrm{y}_{\mathrm{ij}} \text { if } \mathrm{j} \text { is an attribute charge }
\end{aligned}
$$

\section{d. Distance With Ideal Solution}

Distance is an alternative $\mathrm{Ai}$ with a positive ideal solution formulated as follows:

$$
D_{i}^{+}=\sqrt{\sum_{j=1}^{m}\left(y_{i}^{+}-y_{i j}\right) 2}
$$

Distance is an alternative $A_{i}$ with a negative ideal solution formulated as follows:

$$
D_{i}^{-}=\sqrt{\sum_{j=1}^{m}\left(y_{i j}-y_{i}^{-}\right) 2}
$$

e. Preference Value For Any Alternative

The preference value for each alternative $(\mathrm{Vi})$ is given as:

$$
v_{i}=\frac{D_{i}^{-}}{D_{i}^{-}+D_{i}^{+}}
$$

A larger value of $\mathrm{Vi}$ indicates that an alternative $\mathrm{Ai}$ is exactly selected

\section{Methodology}

\section{A. Research Procedures}

Basically TOPSIS not have a specific input models in solving a case. Alternatives can be ranked in order. Therefore, the best alternative is one of the shortest distance to the ideal solution and furthest away with the ideal-negative solution. TOPSIS uses adaptation input model from other methods i.e., AHP, UTA, ELECTRE, TAGUCHI, FUZZY and so forth [23].

In solving a multi-criteria case, AHP compares each criterion using a pairwise comparison matrix for each alternative then the result is a decision matrix that shows the score of each alternative on all criteria. The best alternative is the highest-scoring alternative after being multiplied by the weight vector. While on TOPSIS method, the decision matrix resulting from AHP method is initial capital / initial input in the next calculation.

Research carried out has stages to be done, with the aim to obtain maximum results in decision support. Here are the steps described with the flow diagram:

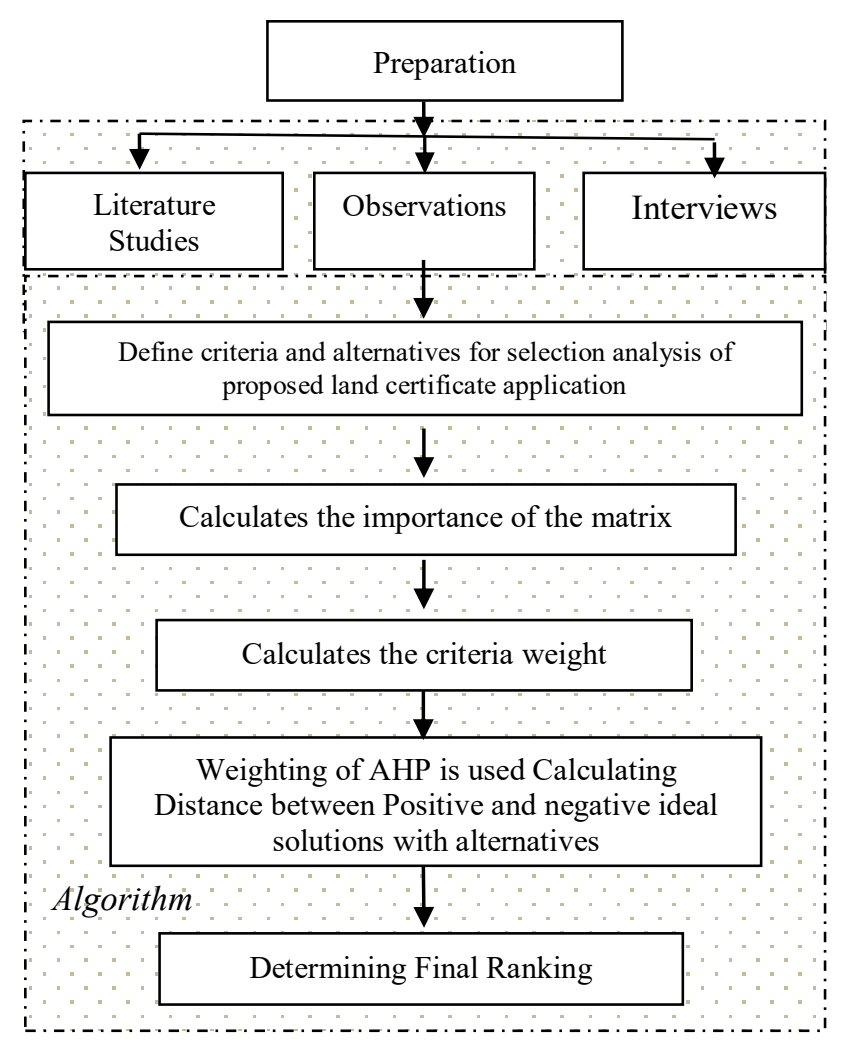

Fig. 1. Research flow diagram

There are several stages of research procedures conducted in this study, namely data collection research, identification and data processing, system design, system implementation, and system testing. 
This testing stage is done after the implementation phase is completed. At this stage the system testing whether the system can run as expected or not. Testing is done in the form of two stages, namely testing of the calculation of the data flow used and testing the performance of the system.

\section{B. Use Case Diagram}

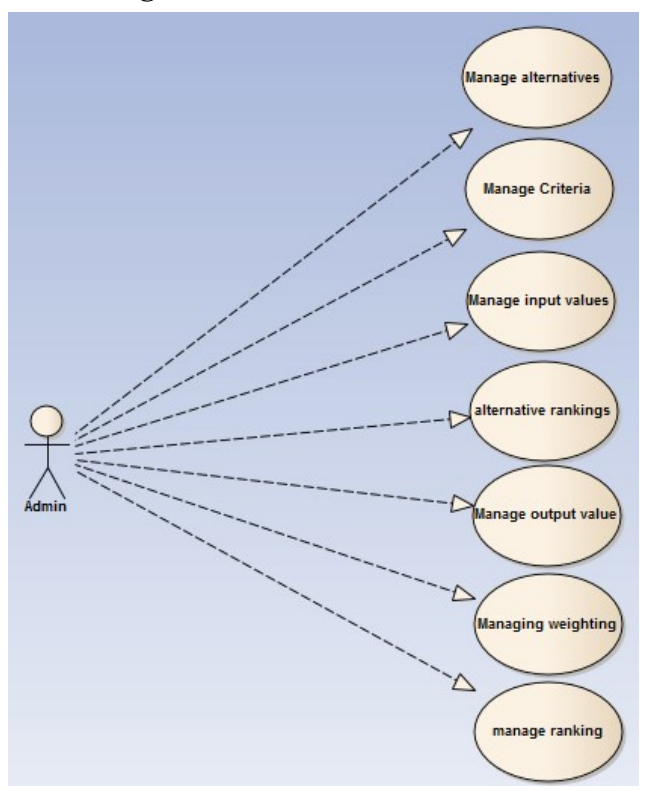

Fig. 2. Use Case Diagram

- Actor: admin and notary

- Use cases: managing criteria, manage alternatives, managing input values, ranking alternatives, manage rankings

The input selection input is entered into this input as many as several alternatives. The data inputted into the input based on the application table. After completion of selection of proposal in input, hence making of certificate of land will be assessed objectively by system based on input data selection proposal of making land costumer certificate. The alternatives are assessed by several alternatives, the number of criteria for each alternative is seven criteria. The values of some of these alternatives are calculated by the weight of the criteria, then the criterion weights is calculated using AHP method. The steps of system algorithm:

1. The input selection input is entered into this input as many as several alternatives. The data inputted into the system based on the application table.

2. An alternative assessment with TOPSIS. After filling in the request for proposal selection input, then the certificates, the land will be assessed objectively by the system based on the data from customers who want to register their land tittle deed. The alternatives are assessed by several alternatives, the number of criteria for each alternative is seven criteria. The values of some of these alternatives are calculated by the weight of the criteria, the criterion weight is calculated using the AHP method.

\section{AHP calculation}

Calculation of AHP, done only once at the beginning, to get the value of weight criteria, then the value of the criteria weight is used continuously for calculation with TOPSIS, AHP assessment is done by Notary (land deed official).

\section{RESULTS AND DISCUSSION}

\section{A. Research result}

Results AHP data processing is the weight of the criteria that TOPSIS will use to perform the TOPSIS process. Stages of Results Data processing using AHP as follows.

Processing AHP data processing to generate criteria weight begins by creating a hierarchical structure, importance level, comparison of importance level, priority vector (pv) or pairwise comparison matrices, and weighted normalization matrices.

\section{Level of Interest}

The values of the interest level table are filled by Notaries on a scale of 1 to 5 . Where value 1 is very unimportant, 2 not important, 3 important enough, 4 important, and 5 is very important. The determination of these values based on the stages of registration of land derived from a notary (land deed official).

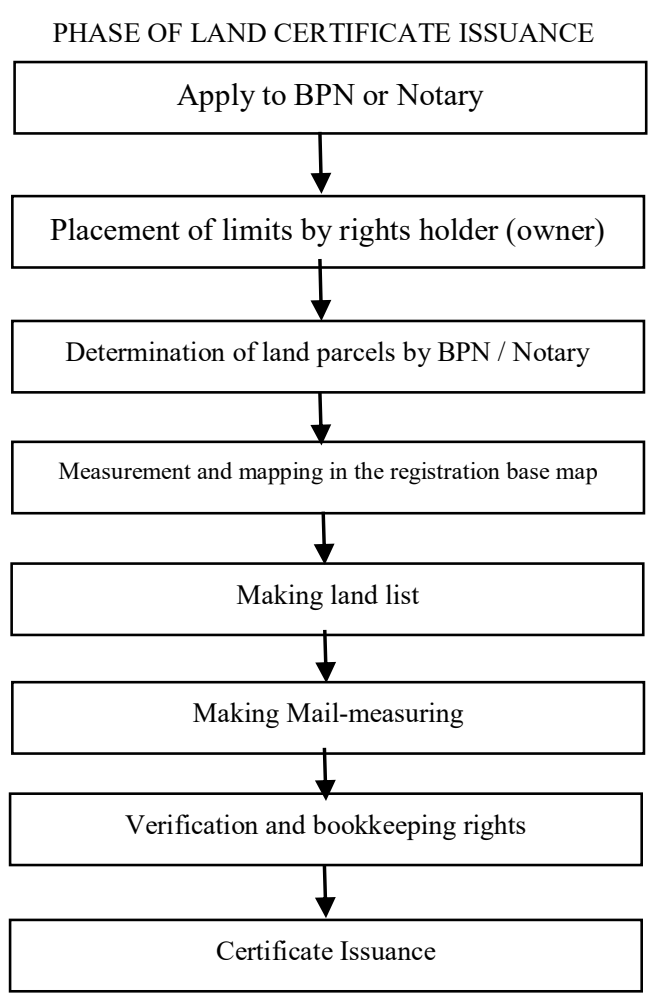

Fig. 3. Circulation Phase of Land Certificate Creation

Explanation of the circulation of soil-making steps:

1. The certificate shall be a certificate of right as referred to in Article 19 paragraph 2 sub-paragraph c of the UUPA (Undang-Undang Pokok Agraria) for land rights, 
management rights, wakaf land, property rights of the apartment units and mortgages, each of which has been recorded in the land books concerned.

2. The land book is a document in the form of a list containing the juridical data and physical data of an entitled registration object.

3. The land registration map is a map that contains technical base points and geographical elements, such as rivers, roads, buildings, and physical boundaries of land.

4. The registration map is a map that describes the plot of land for land-keeping purposes.

5. List of land is a document in the form of a list containing the identity of the plot of land with a numbering system.

6. Measures are documents containing physical data of a plot in the form of maps and descriptions.

7. A list of names is a document in the form of a list containing information on land ownership with rights over the land, or the right management and the ownership of property rights on apartment units by individuals or legal entities.

TABLE IV. LEVEL OF INTERESTS

\begin{tabular}{|c|c|c|c|c|c|c|c|c|}
\hline \multirow[t]{2}{*}{ No } & \multirow{2}{*}{$\begin{array}{l}\text { Name of } \\
\text { Respond } \\
\text { ent }\end{array}$} & \multicolumn{7}{|c|}{ Level of importance criteria } \\
\hline & & $\begin{array}{l}\text { certif } \\
\text { icate }\end{array}$ & $\begin{array}{l}\text { Book } \\
\text { of } \\
\text { land }\end{array}$ & $\begin{array}{l}\text { Bas } \\
\text { e } \\
\text { map }\end{array}$ & $\begin{array}{l}\text { Registr } \\
\text { ation } \\
\text { map }\end{array}$ & $\begin{array}{l}\text { lan } \\
\mathrm{d} \\
\text { list }\end{array}$ & $\begin{array}{l}\text { mea } \\
\text { sure } \\
\text { mail }\end{array}$ & $\begin{array}{l}\text { List } \\
\text { nam } \\
\mathrm{e}\end{array}$ \\
\hline 1 & Manajer & 5 & 5 & 4 & 3 & 3 & 4 & 3 \\
\hline \multicolumn{9}{|c|}{ Interest Rate Scale } \\
\hline 1 & \multicolumn{8}{|c|}{ Very unimportant } \\
\hline 2 & \multicolumn{8}{|c|}{ Not important } \\
\hline 3 & \multicolumn{8}{|c|}{ quite important } \\
\hline 4 & \multicolumn{8}{|l|}{ important } \\
\hline 5 & \multicolumn{8}{|c|}{ Very important } \\
\hline
\end{tabular}

The values of the interest level table are filled by notary PPAT (land deed official) on a scale of 1 to 5 . The determination of those values is based on the decision of the notary itself. In this table there are seven criteria that must be filled in the value which then will be followed by filling table comparison of interests.

\section{Comparison of Interest}

TABLE V. COMPARISON OF INTEREST

\begin{tabular}{|c|c|c|c|c|c|}
\hline \multicolumn{7}{|c|}{ Certificate } \\
\hline $\begin{array}{c}\text { Book of } \\
\text { land }\end{array}$ & $\begin{array}{c}\text { Base } \\
\text { map }\end{array}$ & $\begin{array}{c}\text { Registration } \\
\text { map }\end{array}$ & land list & $\begin{array}{c}\text { measure } \\
\text { mail }\end{array}$ & $\begin{array}{c}\text { List } \\
\text { name }\end{array}$ \\
\hline 1 & $1 / 3$ & $1 / 5$ & $1 / 3$ & $1 / 5$ & $1 / 9$ \\
\hline \multicolumn{7}{|c|}{ Book of land } \\
\hline Base map & Registration map & land list & measure mail & $\begin{array}{c}\text { List } \\
\text { name }\end{array}$ \\
\hline 1 & $1 / 3$ & 1 & 1 & $1 / 5$ \\
\hline \multicolumn{7}{|c|}{ Base map } \\
\hline Registration map & land list & measure mail & List name \\
\hline \multicolumn{2}{|c|}{$1 / 3$} & $1 / 3$ & $1 / 5$ \\
\hline
\end{tabular}

\begin{tabular}{|c|c|c|c|c|c|}
\hline \multicolumn{3}{|c|}{ Registration Map } & \multicolumn{2}{c|}{ Land List } & List Name \\
\hline $\begin{array}{c}\text { List } \\
\text { Land }\end{array}$ & $\begin{array}{c}\text { Measure } \\
\text { Mail }\end{array}$ & $\begin{array}{c}\text { List } \\
\text { name }\end{array}$ & $\begin{array}{c}\text { Measure } \\
\text { Mail }\end{array}$ & $\begin{array}{c}\text { List } \\
\text { Name }\end{array}$ & stats \\
\hline $1 / 7$ & 1 & $1 / 9$ & 1 & $1 / 9$ & $1 / 7$ \\
\hline
\end{tabular}

\begin{tabular}{|l|l|l|l|}
\hline \multicolumn{3}{|c|}{ Book of land } \\
\hline $\boldsymbol{1}$ & greater than 1 just as important \\
\hline 3 & greater than 2 & $1 / 3$ & Smaller 1 \\
\hline 5 & greater than 3 & $1 / 5$ & Smaller 2 \\
\hline 7 & greater than 4 & $1 / 7$ & Smaller 3 \\
\hline 9 & $1 / 9$ & Smaller 4 \\
\hline
\end{tabular}

Completion of comparison table of interest, different from filling table importance level. The difference is on the scale used, the comparison table of interests uses a scale of 1 to 9 . Each one criterion is compared with seven other criteria, by comparing many to one. For example, compare the certificate criteria with seven other criteria, namely the certificate, land books, registration base map, a map application, a list of land, measurement certificate, a list of names. Similarly, with other criteria. The result of this comparison of interest can be made table matrix of pairwise comparison.

\section{Pairwise Comparison Matrices}

TABLE VI. PAIRWISE COMPARISON MATRIX

\begin{tabular}{|c|c|c|c|c|c|c|c|c|}
\hline \multicolumn{10}{|c|}{ vector priority table } \\
\hline Criteria & $\begin{array}{c}\text { certifi } \\
\text { cate }\end{array}$ & $\begin{array}{c}\text { Book } \\
\text { of } \\
\text { land }\end{array}$ & $\begin{array}{c}\text { Base } \\
\text { map }\end{array}$ & $\begin{array}{c}\text { Regi } \\
\text { strati } \\
\text { on } \\
\text { map }\end{array}$ & $\begin{array}{c}\text { land } \\
\text { list }\end{array}$ & $\begin{array}{c}\text { measu } \\
\text { re mail }\end{array}$ & $\begin{array}{c}\text { List } \\
\text { na } \\
\text { me }\end{array}$ & $\begin{array}{c}\text { Priority } \\
\text { Vektor }\end{array}$ \\
\hline Certificate & 1 & 1 & $1 / 3$ & $1 / 5$ & $1 / 3$ & $1 / 5$ & $1 / 9$ & 0.0587 \\
\hline $\begin{array}{c}\text { Book of } \\
\text { Land }\end{array}$ & 1 & 1 & 1 & $1 / 3$ & 1 & 1 & $1 / 5$ & 0.1068 \\
\hline Base map & 3 & 1 & 1 & 1 & $1 / 3$ & $1 / 3$ & $1 / 5$ & 0.1068 \\
\hline $\begin{array}{c}\text { Registration } \\
\text { map }\end{array}$ & 5 & 3 & 1 & 1 & $1 / 7$ & 1 & $1 / 9$ & 0.0587 \\
\hline Land list & 3 & 1 & 3 & 7 & 1 & 1 & $1 / 9$ & 0.0275 \\
\hline $\begin{array}{c}\text { Measure } \\
\text { mail }\end{array}$ & 5 & 1 & 3 & 1 & 1 & 1 & $1 / 7$ & 0.0762 \\
\hline List name & 9 & 5 & 5 & 9 & 9 & 7 & 1 & 0.5340 \\
\hline amount & 27.15 & 13.03 & 14.39 & 19.62 & 12.89 & 11.53 & 1.8 & 0.9688 \\
\hline
\end{tabular}

Scale comparison

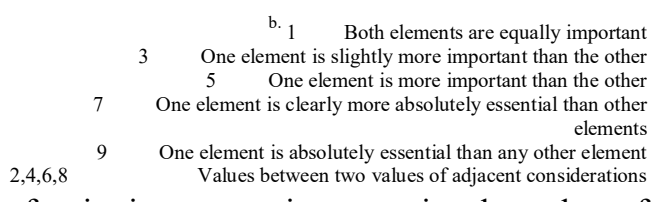

In the table of pairwise comparison matrix, the value of which is filled in the upper triangle is yellow and the value can be retrieved from the table comparison of the interests of the above, for the lower triangle is blue will be filled automatically by means 1 divided by eight criteria to the right and the result will be obtained column-row, then followed by calculating CI, $\mathrm{CI}$ and priority vector.

\section{Matrix Weighted Normalization}


TABLE VII. MATRIX WEIGHTED NORMALIZATION

\begin{tabular}{|c|c|c|c|c|c|c|c|c|c|}
\hline \multicolumn{10}{|c|}{ Table matrix normalization } \\
\hline $\begin{array}{l}\text { Criteri } \\
\text { a }\end{array}$ & $\begin{array}{l}\text { certifi } \\
\text { cate }\end{array}$ & $\begin{array}{l}\text { Book } \\
\text { of } \\
\text { land }\end{array}$ & $\begin{array}{l}\text { Base } \\
\text { map }\end{array}$ & $\begin{array}{l}\text { Regi } \\
\text { strati } \\
\text { on } \\
\text { map }\end{array}$ & $\begin{array}{l}\text { land } \\
\text { list }\end{array}$ & $\begin{array}{l}\text { meas } \\
\text { ure } \\
\text { mail }\end{array}$ & $\begin{array}{l}\text { List } \\
\text { nam } \\
\mathrm{e}\end{array}$ & $\begin{array}{l}\text { Numb } \\
\text { er of } \\
\text { rows }\end{array}$ & $\begin{array}{l}\text { Weigh } \\
\mathrm{t} \\
\text { criteria }\end{array}$ \\
\hline $\begin{array}{l}\text { Certifi } \\
\text { cate }\end{array}$ & $\begin{array}{l}0.036 \\
8 \\
\end{array}$ & $\begin{array}{l}0.076 \\
7 \\
\end{array}$ & $\begin{array}{l}0.022 \\
9 \\
\end{array}$ & $\begin{array}{l}0.010 \\
2\end{array}$ & 0.0256 & $\begin{array}{l}0.017 \\
3 \\
\end{array}$ & $\begin{array}{l}0.05 \\
87 \\
\end{array}$ & 0.2484 & 0.0355 \\
\hline $\begin{array}{l}\text { Book } \\
\text { of } \\
\text { Land }\end{array}$ & $\begin{array}{l}0.036 \\
8\end{array}$ & $\begin{array}{l}0.076 \\
7\end{array}$ & $\begin{array}{l}0.069 \\
5\end{array}$ & $\begin{array}{l}0.016 \\
8\end{array}$ & 0.0776 & $\begin{array}{l}0.086 \\
7\end{array}$ & $\begin{array}{l}0.10 \\
68\end{array}$ & 0.4709 & 0.0673 \\
\hline $\begin{array}{l}\text { Base } \\
\text { map }\end{array}$ & $\begin{array}{l}0.111 \\
6\end{array}$ & $\begin{array}{l}0.076 \\
7\end{array}$ & $\begin{array}{l}0.069 \\
5\end{array}$ & $\begin{array}{l}0.051 \\
0\end{array}$ & 0.0256 & $\begin{array}{l}0.028 \\
6\end{array}$ & $\begin{array}{l}0.10 \\
68\end{array}$ & 0.4698 & 0.0671 \\
\hline $\begin{array}{l}\text { Regist } \\
\text { ration } \\
\text { map }\end{array}$ & $\begin{array}{l}0.184 \\
2\end{array}$ & $\begin{array}{l}0.232 \\
6\end{array}$ & $\begin{array}{l}0.069 \\
5\end{array}$ & $\begin{array}{l}0.051 \\
0\end{array}$ & 0.0111 & $\begin{array}{l}0.086 \\
7\end{array}$ & $\begin{array}{l}0.05 \\
87\end{array}$ & 0.6937 & 0.0991 \\
\hline $\begin{array}{l}\text { Land } \\
\text { list }\end{array}$ & $\begin{array}{l}0.111 \\
6\end{array}$ & $\begin{array}{l}0.076 \\
7\end{array}$ & 02106 & 0.356 & 0.0776 & $\begin{array}{l}0.086 \\
7\end{array}$ & $\begin{array}{l}0.05 \\
87\end{array}$ & 0.9788 & 0.1398 \\
\hline $\begin{array}{l}\text { Measu } \\
\text { re } \\
\text { mail }\end{array}$ & $\begin{array}{l}0.184 \\
2\end{array}$ & $\begin{array}{l}0.076 \\
7\end{array}$ & $\begin{array}{l}0.210 \\
6\end{array}$ & $\begin{array}{l}0.051 \\
0\end{array}$ & 0.0776 & $\begin{array}{l}0.086 \\
7\end{array}$ & $\begin{array}{l}0.07 \\
62\end{array}$ & 0.7629 & 0.1090 \\
\hline $\begin{array}{l}\text { List } \\
\text { name }\end{array}$ & $\begin{array}{l}0.334 \\
8\end{array}$ & $\begin{array}{l}0.383 \\
7\end{array}$ & $\begin{array}{l}0.347 \\
4 \\
\end{array}$ & $\begin{array}{l}0.463 \\
3\end{array}$ & 0.7051 & $\begin{array}{l}0.607 \\
2\end{array}$ & $\begin{array}{l}0.53 \\
40 \\
\end{array}$ & 3.3755 & 0.4822 \\
\hline
\end{tabular}

Weighted normalized matrix table is a table of final value of weighted criteria to be taken, the results of it's own weight is obtained by the number of rows divided by the number of criteria.

\section{B. Results of Data Processing TOPSIS}

TOPSIS data processing is carried out the next stage after the weighting process in the AHP. The process is done on TOPSIS is making Table Decision, Decision Matrix Normalization, Normalized Weighted Decision Matrix, Determining the Ideal Solution Positive and Negative Ideal Solution, Calculating Distance alternative to Ideal Solution Positive and Negative Ideal Solution, and Calculating the Value Preference Each alternative.

TABLE VIII. TABLE DECISION $\left(\mathrm{X}_{\mathrm{H}}\right)$

\begin{tabular}{|c|c|c|c|c|c|c|c|}
\hline \multicolumn{8}{|c|}{ Decision Table (Xij) } \\
\hline \multirow[t]{2}{*}{ Alternative } & \multicolumn{7}{|c|}{ Criteria } \\
\hline & $\begin{array}{l}\text { certif } \\
\text { icate }\end{array}$ & $\begin{array}{c}\text { Book } \\
\text { of } \\
\text { land }\end{array}$ & $\begin{array}{l}\text { Base } \\
\text { map }\end{array}$ & $\begin{array}{c}\text { Registr } \\
\text { ation } \\
\text { map }\end{array}$ & $\begin{array}{c}\text { land } \\
\text { list }\end{array}$ & $\begin{array}{c}\text { meas } \\
\text { ure } \\
\text { mail }\end{array}$ & $\begin{array}{c}\text { List } \\
\text { name }\end{array}$ \\
\hline Ardiansyah & 5 & 4 & 4 & 3 & 4 & 2 & 2 \\
\hline Teguh Suwikto & 4 & 5 & 5 & 5 & 3 & 4 & 2 \\
\hline Ballo & 3 & 5 & 4 & 3 & 5 & 2 & 3 \\
\hline Abdul Rahman & 4 & 5 & 3 & 2 & 4 & 3 & 4 \\
\hline Umar Bakri & 2 & 4 & 2 & 4 & 3 & 4 & 5 \\
\hline Nasir & 2 & 4 & 4 & 3 & 5 & 5 & 4 \\
\hline Andi Arsyad & 4 & 5 & 2 & 5 & 3 & 4 & 3 \\
\hline Sutardin & 3 & 4 & 3 & 4 & 2 & 3 & 4 \\
\hline $\begin{array}{l}\text { M. Yusuf } \\
\text { Ambo Rappe }\end{array}$ & 5 & 4 & 4 & 3 & 4 & 3 & 2 \\
\hline $\begin{array}{l}\text { Dwi Sapto } \\
\text { Harsono }\end{array}$ & 5 & 4 & 3 & 5 & 5 & 4 & 4 \\
\hline & & & & & & $\begin{array}{l}{ }^{\mathrm{c}} \mathrm{Fe} \\
\text { 1. v }\end{array}$ & $\begin{array}{l}\text { ity scale: } \\
\text { nfeasible } \\
\text { teasible } \\
\text { te decent } \\
\text { Feasible } \\
\text { ry decent }\end{array}$ \\
\hline
\end{tabular}

The values in the table is filled by a Notary PPAT a scale of 1 to 5 the same thing on the charging AHP. Ratings in the content based on the results of the data and observations. In this table there are seven grades of criteria that must fill an alternative who will then proceed with charging the normalization table Decision Matrix

\section{Normalization Decision Matrix}

Charging value in Table Normalization Decision Matrix can be calculated using the formula equation (2.3)

The following table is a first step that must be done for the process to normalizing the decision matrix, the values in this table are squaring the value of the decision table.

\section{TABLE IX. SQUARING}

\begin{tabular}{|c|c|c|c|c|c|c|c|}
\hline \multicolumn{8}{|c|}{ Stage 1 Rank each alternative } \\
\hline \multicolumn{8}{|l|}{ Squared } \\
\hline \multirow[t]{2}{*}{ Alternative } & \multicolumn{7}{|c|}{ Criteria } \\
\hline & $\begin{array}{l}\text { certif } \\
\text { icate }\end{array}$ & $\begin{array}{l}\text { Book } \\
\text { of } \\
\text { land }\end{array}$ & $\begin{array}{l}\text { Base } \\
\text { map }\end{array}$ & $\begin{array}{l}\text { Registr } \\
\text { ation } \\
\text { map }\end{array}$ & $\begin{array}{l}\text { land } \\
\text { list }\end{array}$ & $\begin{array}{l}\text { meas } \\
\text { ure } \\
\text { mail }\end{array}$ & $\begin{array}{l}\text { List } \\
\text { name }\end{array}$ \\
\hline Ardiansyah & 25 & 16 & 16 & 9 & 16 & 4 & 4 \\
\hline Teguh Suwikto & 16 & 25 & 25 & 25 & 9 & 16 & 4 \\
\hline Ballo & 9 & 25 & 16 & 9 & 25 & 4 & 9 \\
\hline Abdul Rahman & 16 & 25 & 9 & 4 & 16 & 9 & 16 \\
\hline Umar Bakri & 4 & 16 & 4 & 16 & 9 & 16 & 25 \\
\hline Nasir & 4 & 16 & 16 & 9 & 25 & 25 & 16 \\
\hline Andi Arsyad & 16 & 25 & 4 & 25 & 9 & 16 & 9 \\
\hline Sutardin & 9 & 16 & 9 & 16 & 4 & 9 & 16 \\
\hline $\begin{array}{l}\text { M. Yusuf } \\
\text { Ambo Rappe }\end{array}$ & 25 & 16 & 16 & 9 & 16 & 9 & 4 \\
\hline $\begin{array}{ll}\text { Dwi } & \text { Sapto } \\
\text { Harsono } & \\
\end{array}$ & 25 & 16 & 9 & 25 & 25 & 16 & 16 \\
\hline Amount & 149 & 196 & 124 & 147 & 154 & 124 & 119 \\
\hline square root & 12.21 & 14.00 & 11.14 & 12.12 & 12.41 & 11.14 & 10.91 \\
\hline
\end{tabular}

TABLE X. NORMALIZATION DECISION MATRIX

\begin{tabular}{|l|l|l|l|l|l|l|l|}
\hline Normalization of decision matrix (rij) \\
\hline Alternative & \multicolumn{7}{|l|}{ Criteria } \\
\cline { 2 - 8 } & $\begin{array}{l}\text { certif } \\
\text { icate }\end{array}$ & $\begin{array}{l}\text { Book } \\
\text { of } \\
\text { land }\end{array}$ & $\begin{array}{l}\text { Base } \\
\text { map }\end{array}$ & $\begin{array}{l}\text { Registr } \\
\text { ation } \\
\text { map }\end{array}$ & $\begin{array}{l}\text { land } \\
\text { list }\end{array}$ & $\begin{array}{l}\text { meas } \\
\text { ure } \\
\text { mail }\end{array}$ & $\begin{array}{l}\text { List } \\
\text { name }\end{array}$ \\
\hline Ardiansyah & 2.0481 & 1.1429 & 1.4368 & 0.7423 & 1.2893 & 0.3592 & 0.3667 \\
\hline Teguh Suwikto & 1.3108 & 1.7857 & 2.2451 & 2.0620 & 0.7252 & 1.4368 & 0.3667 \\
\hline Ballo & 0.7373 & 1.7857 & 1.4368 & 0.7423 & 2.0146 & 0.3592 & 0.8250 \\
\hline Abdul Rahman & 1.3108 & 1.7857 & 0.8082 & 0.3299 & 1.2893 & 0.8082 & 1.4667 \\
\hline Umar Bakri & 0.3277 & 1.1429 & 0.3592 & 1.3197 & 0.7252 & 1.4368 & 2.2917 \\
\hline Nasir & 0.3277 & 1.1429 & 1.4368 & 0.7423 & 2.0146 & 2.2451 & 1.4667 \\
\hline Andi Arsyad & 1.3108 & 1.7857 & 0.3592 & 2.0620 & 0.7252 & 1.4368 & 0.8250 \\
\hline Sutardin Yusuf & 0.7373 & 1.1429 & 0.8082 & 1.3197 & 0.3223 & 0.8082 & 1.4667 \\
\hline $\begin{array}{l}\text { M. Y. } \\
\text { Ambo Rappe }\end{array}$ & 2.0481 & 1.1429 & 1.4368 & 0.7423 & 1.2893 & 0.8082 & 0.3667 \\
\hline $\begin{array}{l}\text { Dwi Sapto } \\
\text { Harsono }\end{array}$ & 2.0481 & 1.1429 & 0.8082 & 2.0620 & 2.0146 & 1.4368 & 1.4667 \\
\hline
\end{tabular}

\section{Normalization Weighted Decision Matrix}

TOPSIS next stage, a weighted decision matrix normalization which is calculated on the AHP process, which calculates the weighted normalization matrix, which results in weight criteria. Elements of the normalized weighted matrix is the product of the weight criteria in AHP with elements (rij) in the Decision Matrix normalization table. Table weighting criteria obtained from AHP calculation.

\section{TABLE XI. CRITERIA WEIGHTS}

\begin{tabular}{|l|l|l|l|l|l|l|}
\hline \multicolumn{2}{|l|}{ Wighted Criteria } \\
\hline certificate & $\begin{array}{l}\text { Book } \\
\text { of land }\end{array}$ & $\begin{array}{l}\text { Base } \\
\text { map }\end{array}$ & $\begin{array}{l}\text { Registration } \\
\text { map }\end{array}$ & $\begin{array}{l}\text { land } \\
\text { list }\end{array}$ & $\begin{array}{l}\text { measure } \\
\text { mail }\end{array}$ & $\begin{array}{l}\text { List } \\
\text { name }\end{array}$ \\
\hline 2.0481 & 1.1429 & 1.4368 & 0.7423 & 1.2893 & 0.3592 & 0.3667 \\
\hline
\end{tabular}


TABLE XII. NORMALIZED WEIGHTED DECISION MATRIX

\begin{tabular}{|c|c|c|c|c|c|c|c|}
\hline \multirow[t]{2}{*}{ Alternative } & \multicolumn{7}{|c|}{ Criteria } \\
\hline & $\begin{array}{l}\text { certif } \\
\text { icate }\end{array}$ & $\begin{array}{l}\text { Book } \\
\text { of } \\
\text { land }\end{array}$ & $\begin{array}{l}\text { Base } \\
\text { map }\end{array}$ & $\begin{array}{l}\text { Registr } \\
\text { ation } \\
\text { map }\end{array}$ & $\begin{array}{l}\text { land } \\
\text { list }\end{array}$ & $\begin{array}{l}\text { meas } \\
\text { ure } \\
\text { mail }\end{array}$ & $\begin{array}{l}\text { List } \\
\text { name }\end{array}$ \\
\hline Ardiansyah & 0.0727 & 0.0769 & 0.0964 & 0.0736 & 0.1803 & 0.0392 & 0.1768 \\
\hline Teguh Suwikto & 0.0465 & 0.1201 & 0.1507 & 0.2043 & 0.1014 & 0.1566 & 0.1768 \\
\hline Ballo & 0.0262 & 0.1201 & 0.0964 & 0.0736 & 0.2817 & 0.0392 & 0.3978 \\
\hline Abdul Rahman & 0.0465 & 0.1201 & 0.0542 & 0.0327 & 0.1803 & 0.0881 & 0.7073 \\
\hline Umar Bakri & 0.0116 & 0.0769 & 0.0241 & 0.1308 & 0.1014 & 0.1566 & 1.1051 \\
\hline Nasir & 0.0116 & 0.0769 & 0.0964 & 0.0736 & 0.2817 & 0.2447 & 0.7073 \\
\hline Andi Arsyad & 0.0465 & 0.1201 & 0.0241 & 0.2043 & 0.1014 & 0.1566 & 0.3978 \\
\hline Sutardin & 0.0262 & 0.0769 & 0.0542 & 0.1308 & 0.0451 & 0.0881 & 0.7073 \\
\hline $\begin{array}{l}\text { M. Yusuf } \\
\text { Ambo Rappe }\end{array}$ & 0.0727 & 0.0769 & 0.0964 & 0.0736 & 0.1803 & 0.0881 & 0.1768 \\
\hline $\begin{array}{ll}\text { Dwi } & \text { Sapto } \\
\text { Harsono } & \end{array}$ & 0.0727 & 0.0769 & 0.0542 & 0.2043 & 0.2817 & 0.1566 & 0.7073 \\
\hline
\end{tabular}

\section{Determining the Ideal Solution Positive and Negative Ideal Solution}

Stages ideal solution for the positive $(+)$ and negative ideal solution (-) can be based weighted normalization matrix. The elements of the matrix $\mathrm{A}^{+}$in the table below is the maximum value of each column in Table Normalization Weighted Decision Matrix, while the elements of the matrix A - in the table below are the minimum value of each column in Table Normalization Weighted Decision Matrix, Table XIII.

TABLE XIII. DETERMINING THE IDEAL SOLUTION POSITIVE AND NEGATIVE IDEAL SOLUTION

\begin{tabular}{|l|l|l|l|l|l|l|}
\hline \multicolumn{7}{|l|}{ Stage 3: Ideal positive and negative solutions } \\
\hline $\mathrm{Y}+$ & 0.0727 & 0.1507 & 0.2043 & 0.2817 & 0.2447 & 1.1051 \\
\hline $\mathrm{Y}-$ & 0.0116 & 0.0241 & 0.0327 & 0.0451 & 0.0392 & 0.1768 \\
\hline
\end{tabular}

\section{Calculating Distance alternative to Ideal Solution Positive and Negative Ideal Solution}

At this stage the distance determined is not only the shortest distance, but the farthest distance can be calculated value. So this step is to determine the distance of each alternative against the positive ideal solution and within each alternative against the negative ideal solution. Distance is an alternative Ai with positive ideal solution formulated. Distance is an alternative Ai formulated with negative ideal solution, Table XIV.

TABLE XIV. DISTANCE TO THE IDEAL SOLUTION

\begin{tabular}{|l|l|l|l|l|l|l|}
\hline \multicolumn{6}{|l|}{ Stage 3: Ideal positive and negative solutions } \\
\hline Y & 0.0727 & 0.1507 & 0.2043 & 0.2817 & 0.2447 & 1.1051 \\
\hline Y- & 0.0116 & 0.0241 & 0.0327 & 0.0451 & 0.0392 & 0.1768 \\
\hline
\end{tabular}

\section{Calculating the Value Preference Every Alternative}

This stage is the final stage determined for ranking TOPSIS or known by calculating the preference value for each alternative. Preference value for each alternative (vi) the relative proximity of each alternative is calculated based on the equation of the formula. $V_{i}$ larger value indicates that the alternative $A_{i}$ appropriately selected. As the following Table $\mathrm{XV}$.
TABLE XV. Distance TO THE IDEAL SOLUTION

\begin{tabular}{|l|l|l|}
\hline Alternative & \multicolumn{2}{|l|}{ The preference value of each } \\
alternative & \\
\hline Ardiansyah & V1 & 0.1440 \\
\hline Teguh Suwikto & V2 & 0.2099 \\
\hline Ballo & V3 & 0.3081 \\
\hline Abdul Rahman & V4 & 0.5335 \\
\hline Umar Bakri & V5 & 0.7862 \\
\hline Nasir & V6 & 0.5929 \\
\hline Andi Arsyad & V7 & 0.2939 \\
\hline Sutardin & V8 & 0.5176 \\
\hline M. Yusuf Ambo Rappe & V9 & 0.1565 \\
\hline Dwi Sapto Harsono & V10 & 0.5972 \\
\hline
\end{tabular}

\section{CONCLUSION}

The result of this research shows that fewer variables could represent all the variables and can assess and rank with the quality of good decisions and provide variables that focused on improvement.

\section{REFERENCES}

[1] A. Ishizaka, and H.N. Nguyen, "Calibrated fuzzy AHP for current bank account selection", Expert Systems with Applications 40, pp. 3775 3783,2013

[2] A. Kelemenis, K. Ergazakis, D. Askounis, "Support managers selection using an extension of AHP-TOPSIS", Expert Systems with Applications 38, pp. 2774-2782, 2011.

[3] D. D. Umar, Komputerisasi Pengambilan Keputusan (Desicion Making Computerization), Jakarta : Elex Media Komputindo, 2001.

[4] E. Turban and J. E., Aronson. Decision Support Systems and Intelligent Systems. 6th edition, New Jersey: Prentice Hall, 2001.

[5] G. Buyokozkan, dan G. Cifci, "A novel hybrid MCDM approach based on fuzzy DEMATEL, fuzzy ANP and AHP-TOPSIS to evaluate green suppliers", Expert Systems with Applications 39, pp. 3000-3011, 2012.

[6] I. Ertugrul, and N. Karakasoglu, "Performance evaluation of Turkish cement firms with fuzzy analytic hierarchy process and TOPSIS methods", Expert Systems with Applications 36, pp. 702-715, 2009.

[7] Ingham, Consumer Credit Fundamentals, New Jersey: Prentice Hall, 2004.

[8] K.B. Bulgurcu, "Application of TOPSIS Technique for Financial Performance Evaluation of Technology Firms in Istanbul Stock Exchange Market", Expert Systems with Applications 36, pp. 702-715, 2012.

[9] M. Behzadian, K.S. Otaghsara, M. Yazdani, and J. Ignatius, “A state-of the-art survey of TOPSIS applications", Expert Systems with Applications 39, pp. 13051-13069, 2012.

[10] M. Dagdeviren, S. Yavuz, dan N. Kilinc, "Weapon selection using the AHP and TOPSIS methods under fuzzy environment", Expert Systems with Applications 36, pp. 8143-8151, 2009.

[11] L. Dymova, P. Sevastjanov, dan A. Tikhonenko, “A direct interval extension of TOPSIS method", Expert Systems with Applications 40, pp. 4841-4847, 2013.

[12] T. Y. Ic, and M. Yurdakul, "Development of a decision support system for machining center selection", Expert Systems with Applications 36, pp. 3505-3513, 2009.

[13] T.Y. Ic, "Development of a credit limit allocation model for banks using an integrated AHP-TOPSIS and linear programming", Expert Systems with Applications 39, pp. 5309-5316, 2012.

[14] R. H. Sparague, and H. J. Watson, Decision Support Systems: Putting Theory Into Practice, New Jersey: Prentice Hall, 1993.

[15] S. Kusumadewi, et. al, Fuzzy Multi-Attribute Decision Making (Fuzzy MADM), Yogyakarta: Graha Ilmu, 2006

[16] S. Mulyono, Teori Pengambilan Keputusan (Decision Making Theory), Jakarta: Lembaga Penerbit Fakultas Ekonomi UI, 1996. 
[17] S. Novkovic, "Defining the co-operative difference", The Journal of Socio-Economics 37, pp. 2168-2177, 2008.

[18] S. P. Florianus, Tata Cara Mengurus Sertifikat Tanah (Land Certificate Administration), Jakarta: Transmedia Pustaka, 2007.

[19] S. Rahman, H. Odeyinka, S. Perera, dan Y. Bi, Product-cost modelling approach for the development of a decision support system for optimal roofing material selection, Expert Systems with Applications 39, pp. 6857-687, 2012.

[20] Tominanto, Sistem Pendukung Keputusan dengan Metode AHP untuk Penentuan Prestasi Kinerja Dokter pada RSUD Sukoharjo, INFOKES VOL. 2 NO. 1, pp. 56-78, 2012.
[21] W. J. Wen, and C. C. Hsue, and H. Kun-Cheng, "Fuzzy hierarchical TOPSIS for supplier selection", Applied Soft Computing 9, pp. 377386, 2009.

[22] X. Zhu, F. Wang, C. L. Liang, S. Jianping and Xiaolei, "Quality credit evaluation based on TOPSIS : Evidence from air-conditioning market in China”, Procedia Computer Science 9, pp. 1256 - 1262, 2012.

[23] Suprihatin, I. T. R. Yanto, N. Irsalinda, T. Purwaningsih, Haviluddin and A. P. Wibawa, "A performance of modified fuzzy C-means (FCM) and chicken swarm optimization (CSO)," 2017 3rd International Conference on Science in Information Technology (ICSITech), Bandung, 2017, pp. 